language in icon epigraphs. However, sometimes certain elements of the vernacular were transferred into the icon inscriptions without any change. Such examples bear witness to the development of the Old Ukrainian language.

Some words found in the icon inscriptions are attested in the Dictionary of the Old Ukrainian language of the 14th and 15 th centuries or other lexicons but some of them cannot be found in any dictionary.

Verifying Kots-Hryhorchuk's thesis, the author also argues that the infiltration of the vernacular into the icon inscription began not in the mid-15th century, but much earlier, at least from the 14th century and increased gradually. He points out that the study of the icon inscriptions promises big prospects also for philological research.

Keywords: Old Ukrainian language, icon inscriptions, Dictionary of the Old Ukrainian language of the 14 th and 15 th centuries.

\title{
Мар'яна Левицька
}

\section{Сюжети Неділь П'ятидесятниці в іконостасних циклах Луки Долинського: символіка та іконографія}

Розглянуто окрему групу релігійних композицій Луки Долинського, виконаних для кількох храмів в період із 1770 по 1820-ті рр., об’єднаних спільною тематикою. В фокусі дослідження - аналіз символіки та іконографії сцен із циклу Неділь П'ятидесятниці та особливості художнього вирішення вказаних сюжетів у контексті розвитку унійної образотворчої традиції XVIII - початку XIX ст. У статті визначено передумови зміни пріоритетів у відборі релігійних сюжетів для унійних церков впродовж XVIII ст. Актуальність розвідки доповнюється порівняльним контекстом із виявлення взаємовпливів у західній та східній іконографії сцен Неділь П’ятидесятниці.

Ключові слова: цикл Неділь П’ятидесятниці, богословська основа, іконографічна програма, символіка мотивів

Діяльність львівського художника Луки Долинського припала на період динамічних змін в українському іконописі XVIII ст., і сам маляр вважався значним новатором у цьому процесі. Художник був тісно пов'язаний із вищим середовищем василіанського кліру, про що свідчать його монументальні програмні цикли у соборі Св. Юра, в Онуфріївській церкві монастиря Чину святого Василія Великого (далі - ЧСВВ) (втрачені) та Успенській церкві Почаєва [1, с. 9; 2, с. 40-41; 3, с. 189-1928; 4, с. 106-108]. Загалом, релігійні композиції Л. Долинського були позначені не тільки виразними змінами стилістичного характеру, але й пов'язані із ширшим контекстом змін в літургійній, богословській сферах, інспірованих Замойським синодом 1720 р. та впроваджуваних василіанським духовенством [5, с. 58-61; 6, с. 236-237]. Працюючи над іконостасами названих храмів, Долинський модифікував традиційний репертуар сюжетів, вводячи в них окремі нові композиції. Серед тем, які постійно зустрічаються в доробку художника є сюжети Неділь П'ятидесятниці. Тому варто детальніше проаналізувати поширення 
тематики Неділь в українському іконописі через їі богословську основу, виділити тематичні пріоритети серед окремих композицій циклу, виявити особливості іконографії та символіку мистецьких вирішень саме у творах Л. Долинського. Подібний аналіз дозволить встановити зв'язки між текстом/словом та зображенням, коли зображене в іконописі стає “свідченням" на рівні чуттєвого досвіду і досвіду віри.

Необхідно зазначити, що хоча доробок Л. Долинського був предметом зацікавлень кількох поколінь українських дослідників (М. Голубця [1], В. Щурата [2], В. Вуйцика [7; 8], В. Овсійчука [9], О. Сидора [10], В. Александровича [3] та інші), проте більшість дослідників обмежувалися біографічним нарисом життя і творчості художника, уточненням інформації про корпус його творів тощо. Продовжуючи вивчення мистецької спадщини художника $[11 ; 12]$ доцільно проаналізувати ії у глибшому богословському контексті релігійного мистецтва XVIII ст. Зокрема, особливу увагу приділено живописним композиціям на теми неділь П'ятидесятниці, що є невід'ємною частиною літургійного року, та доповнює цикл 12 празників в українському іконостасі.

Пасхальна неділя відкривала період, який був одною “великою неділею”, “тижнем тижнів” (св. Василій Великий), і закінчувався святом П'ятидесятниці. Літургія періоду П'ятидесятниці розкривала глибоку богословську ідею спасіння: Бог, який свого часу звертався до Мойсея, відкрив Себе в Ісусі Христі [13; 14]. Літургійний рік досягає своєї кульмінації у Пасхальну ніч, але не зупиняється на ній, і період П'ятидесятниці- це розвиток благодаті Пасхальної неділі, а ії плід-зішестя Святого Духа. В день П'ятидесятниці була закладена Вселенська апостольська церква (Діян. 2:1-4; Діян. 2:41-47; Ів. 7:37-52; 8:12). В цей день апостоли отримали особливі дари від Святого Духа: мудрість, віру, здатність здійснювати чудеса, зцілювати, пророчити, дар знання і тлумачення різних мов. [14, с. 393-400; 15]. Відокремлення свят Вознесіння Господнього та Зіслання Святого Духа відбулося у IV ст., з V ст. на Сході і на Заході вже було відоме свято Вознесіння [16]; літургійні форми після Другого Ватиканського собору підтвердили статус П’ятидесятниці як фінального свята - "печатки Пасхи". Усі богослужіння протягом 50 днів від Воскресіння до Зіслання Святого Духа, літургії усіх неділь були кодифіковані у “Тріоді квітній” (напр., Почаївського видання 1747 р.) (iл. 1). Вона починалася від Квітної неділі, на третій день Пасхи (Луки і Клеопи) (Лк. 24:12-35) згадувано про жінок-мироносиць і явлення Христа учням на шляху до Емауса. Наступні неділі “Тріоді квітної” присвячувалися свідченням божественної слави Христа та видимої присутності Бога в його Церкві [16; 17].

За церковним календарем цикл неділь П'ятдесятниці складається із шести подійсвідчень віри і чудес Христа: "Увірування Томи”, “Жони-мироносиці”, “Зцілення розслабленого/Зцілення у Витезді”, "Христос і самарянка", “Зцілення сліпонародженого”, (Вознесіння), “Неділя отців Першого Вселенського собору”, “Явління Христа Петру Александрійському” і завершується святом Зіслання Святого Духа. Впродовж неділь П'ятидесятниці на літургії читається Євангеліє від Йоана, Євангеліє, що найбільше свідчить про Воскреслого Христа: таким чином події і теми П'ятидесятниці допомагають утвердитися у вірі $[15 ; 17 ; 19$, с. 154].

Перераховані сюжети в тематичному репертуарі українського іконопису поширилися із XVII ст. і відіграли досить важливу роль для його іконографічного збагачення. Про тематику й іконографічні особливості цього циклу в названих іконостасах писали 


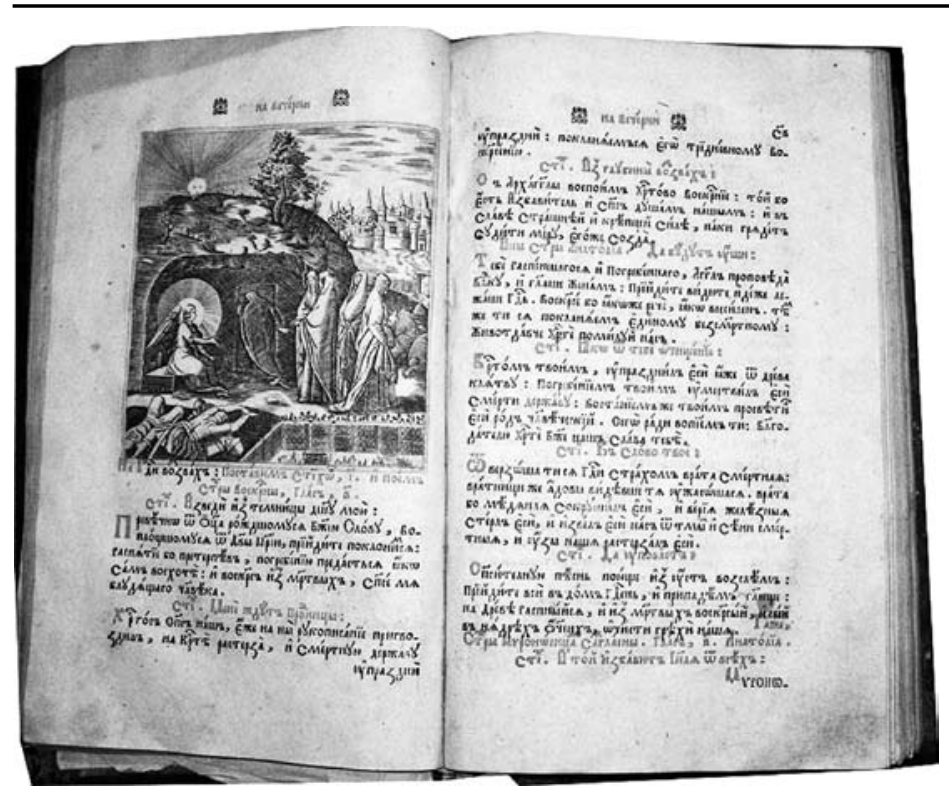

Іл. 1. “Тріодь квітна”. Почаӥв, 1747 p.

такі дослідники: Р. Зілінко, Я. Гємза, В. Ярема та інші $[20$, с.143; 21 , с. $18-22 ; 22$, с. 44]. Генеза і розвиток цих сюжетів були безпосередньо пов'язані з літургійною традицією, про що свідчить поширення графічних ілюстрацій до циклу Неділь у богослужбових книгах другої половини XVII ст. - XVIII ст. Київської, Львівської та Почаївської друкарень. Характерно, що цикл Неділь зустрічається переважно в іконостасах теренів колишньої Речі Посполитої (території Поділля, Галичини, частини Білорусії), так що окремі дослідники пов’язали поширення циклу із явищем “окциденталізації” іконопису під впливом західних взірців [23, с. 126-128; 24, с. 130-135].

Дослідниця М. Пелех вказувала на наявність сюжетів Неділь на пределлах іконостасів XVII ст. (церква Преображення в с. Зарудці, церква Св. Димитрія у Львові на Знесінні та інші) [25, с. 164-165]. Одним із перших зразків введення циклу Неділь (1667 р.) був іконостас церкви Св. Миколая у Кам’янці-Бузькій (Львівщина); на другу половину XVII ст. припадає поява цих сюжетів також в іконостасах Успенської церкви у Львові; церкви Св. Трійці у Жовкві; церкви Св. Миколая в Любачові (Польща) (тепер знаходиться у греко-католицькій катедрі Св. Йоана у Перемишлі) [22], церкви Вознесіння у Волиці-Деревлянській та інших [20, с. 147]. Радше як виняток у розвитку цієї тематики на теренах Лівобережної України сприймається Сорочинський іконостас: сюжети Неділь $є$ в частині, що відповідає освяченню престолу - “Зіслання Св. Духа". Зауважимо, що на думку Д. Горбачова, ймовірним автором Сорочинського іконостасу був Алімпій Галик (учень із малярні Києво-Печерської лаври, який походив із Галичини і добре знав галицьку традицію [20, с.147].

Один 3 найвідоміших іконостасів зламу XVII-XVIII ст., доповнений тематикою Неділь П'ятидесятниці. Це жовківський іконостас Івана Рутковича (1697-1699 рр. НМЛ). Зокрема, у ньому наявні сюжети "Увірування Томи”, “Жони мироносиці”, “Зцілення розслабленого/Овеча купіль”, "Христос і самарянка", “Зцілення сліпого” [20, с.145]. Проте в іконописі кінця XVIII - початку XIX ст. згадані композиції зустрічаються в іконостасах вже рідше: в церкві Вознесіння у Курівцях поблизу Тернополя (“Христос і самарянка") [20, с. 146].

Характерно, що у творчості Л. Долинського композиції циклу Неділь наявні у більшості його монументальних проектів, які замовляли і затверджували найвищі пред- 
ставники унійного кліру кінця XVIII - початку XIX ст. (львівські єпископи, ігумени монастирів чи архімандрити ЧСВВ). Загалом, у храмах Львова та Почаєва художник послідовно виконував чотири теми: “Увірування Томи”, “Зцілення розслабленого”, "Христос і самарянка" та “Зцілення сліпонародженого” (табл. 1). Звертаючись до тлумачень цих євангельських уривків, що читалися на відповідних недільних літургіях, можна виділити спільне послання, яке об'єднувало ці чотири теми: в них йшлося про питання віри у Воскресіння і божественну природу Христа [15; 16]. Таким чином, євангеліст Йоан у різний спосіб звертає увагу вірних на складні питання взаємодії знання і віри, матеріального і духовного досвіду, проходження різних рівнів у сприйнятті, розумінні, усвідомленні правд віри. У розкритті символіки сюжетів опираємося безпосередньо на євангельські тексти [13] та на відповідні усталені тлумачення і коментарі до Святого Письма [17]. При цьому зупиняємося на найсуттєвіших “повідомленнях", які транслюються через кожен окремий іконографічний мотив. Оскільки в дослідженні йдеться про особливості іконографії та символіки циклу Неділь не загалом, а у доробку одного майстра, у конкретному архітектурно-церковному просторі, вважаємо за доцільне зробити огляд сюжетів за хронологією їх виконання, а не за усталеною послідовністю літургійних євангельських читань.

Табл. 1

Репертуар тем Неділь П'ятидесятниці у монументальних проектах Л. Долинського

\begin{tabular}{|c|c|c|c|}
\hline Увірування Томи & $\begin{array}{l}\text { Зцілення розсла- } \\
\text { бленого/ Витезда }\end{array}$ & $\begin{array}{c}\text { Христос і сама- } \\
\text { рянка }\end{array}$ & $\begin{array}{l}\text { Зцілення сліпона- } \\
\text { родженого }\end{array}$ \\
\hline $\begin{array}{l}- \text { Успенський со- } \\
\text { бор Почаївського } \\
\text { монастиря } \\
1810 \text { рр.) }\end{array}$ & $\begin{array}{l}- \text { Успенський со- } \\
\text { бор Почаївського } \\
\text { монастиря } \\
1810 \text { рр.) }\end{array}$ & $\begin{array}{l}\text { - Церква Зіслання } \\
\text { Святого Духа (1784- } \\
\text { 1788/? рр.) } \\
\text { - Успенський со- } \\
\text { бор Почаївського } \\
\text { монастиря (1807- } \\
1810 \text { рр.) }\end{array}$ & $\begin{array}{l}\text { - Собор Св. Юра } \\
\text { (1777-1778 рр.) } \\
\text { - Церква Зіслання } \\
\text { Святого Духа (1784- } \\
\text { 1788/? рр.) } \\
\text { б Успенський со- } \\
\text { бор Почаївського } \\
\text { монастиря (1807- } \\
1810 \text { рр.) }\end{array}$ \\
\hline
\end{tabular}

Першим у списку великих малярських проектів Долинського був собор Св. Юра, де традиційні іконостасні чини перемістилися у простір святилища. Причому, в соборі Св. Юра розташування сюжетів празничкового циклу у вівтарі здається досить довільним, проте у ньому прослідковується загальна тема “Воплочення Слова” (через сцени із життя Марії та Христа) та акцентується зміст відкуплення гріхів і Воскресіння. Зокрема, у нижньому регістрі декоративної боазерії ${ }^{1}$ святилища присутні теми Пасхального циклу: “Воскресіння”, “Вознесіння”, “Зіслання Святого Духа”, які в теологічному розумінні втілювали еклезіологію “Церкви тріумфуючоі”” (Ecclesia triumphat), - Христос, що переміг смерть стає запорукою духовного спасіння. Треба пам'ятати, що образи у святилищі собору не були призначені для загального огляду,

1 "Боазерія" (з пол. Boazeria) - декоративна обшивка дерев'яними панелями, нерідко конструкція зі складним профілем; термін використаний М. Драганом саме щодо вівтаря собору Св. Юра [26]. 


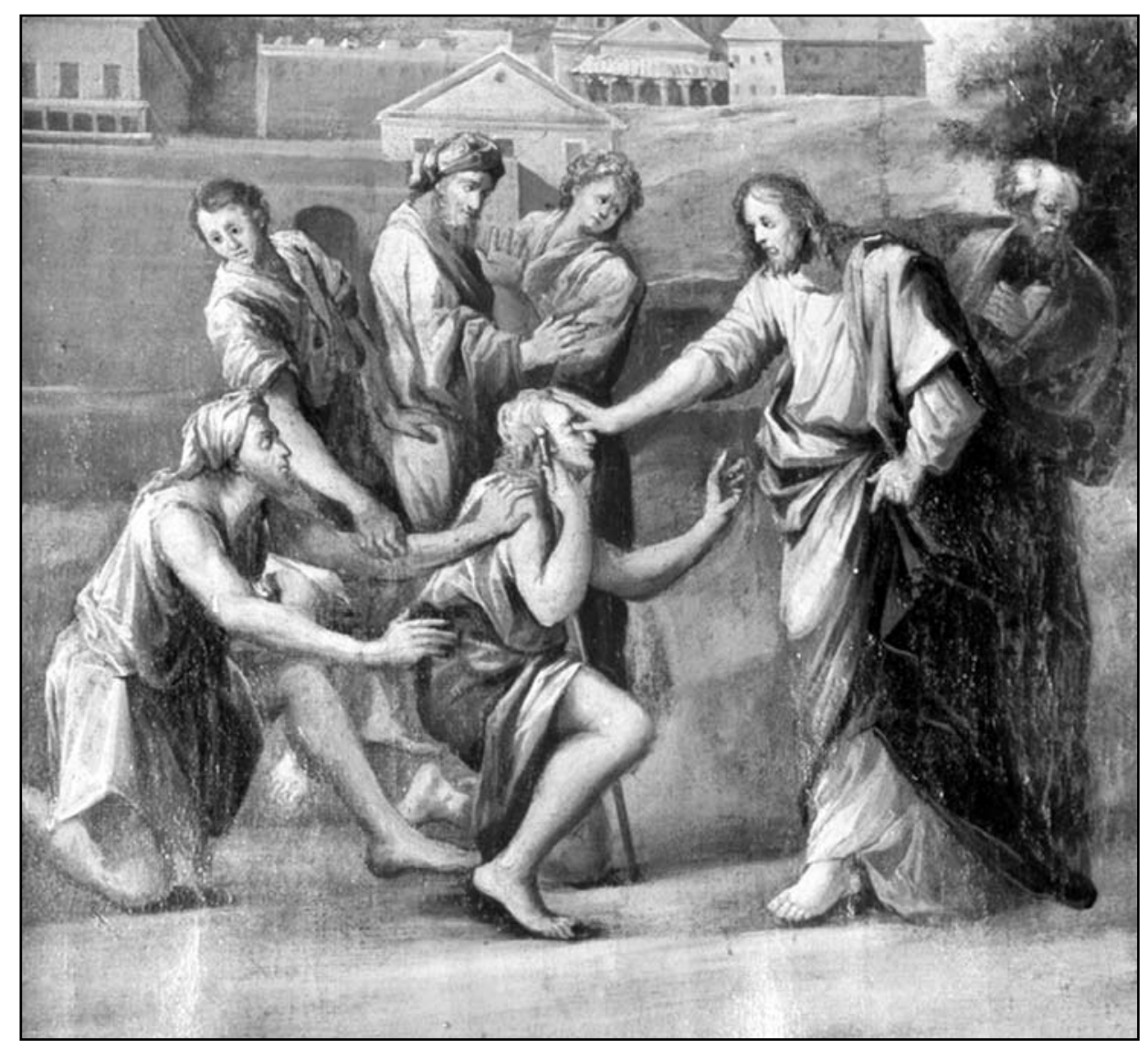

Іл. 2. “Зиілення сліпонародженого”, фрагмент. Худ. Л. Долинський. Собор Св. Юра. Львів, 1777 .

тому й програма їх, очевидно, була орієнтована на духовенство, глибше обізнане із теологічними питаннями й літургійними практиками. В цьому (умовно названому нами “празничковим”) циклі немає оповідальності, а $є$ акцент на духовне “переживання" євангельських тем. В такому контексті видається, що апробовані духовенством (єпископами Л. Шептицьким та згодом П. Білянським) і виконані художником дві композиції: “Омовіння ніг апостолам” та “Зцілення сліпонародженого” (iл. 2) стають концентрованим виразом теми священства/служіння, і духовного прозріння людини, iii відкритості до правд віри, що було метою і покликанням Церкви.

Сюжет “Зцілення сліпонародженого” у Святому Письмі (Ів. 9:1-38) опирається на низку текстів (про дар зцілення від сліпоти - Ic. 42:7; Ic. 29:18; Мт. 9:28-30; Мк. 10:46-52; Посл. Свр. 11:6 [13]) і тут завжди йдеться про перевірку віри. Змістовно, найсутніснішою частиною євангельського тексту є уривок, де Ісус здійснює чудесне зцілення (Йо. 9:6-7), після якого проголошує: “Я є світло світу...” (Йо. 9:5). Характерною особливістю іконографії цієї сцени є те, що в численних випадках оздоровлень Христос рідко торкається потребуючих, але у випадках зі сліпими завжди робить це, - щоб незрячий відчув дотик. Символічною кульмінацією події є текст Євангелія від Йоана 
(Йо. 9:38), який стверджує, що для віри потрібне знання і воля, коли зцілений сліпий говорить “Вірую, Господи!”. Наявність цього сюжету в трьох головних проектах Долинського (впродовж 1770-1820-х рр.), замовлених верхівкою унійного кліру, засвідчує важливий символічний зміст цієї сцени в тогочасних малярських програмах.

Втім, порівняльна табл. 2 дозволяє також виявити і проаналізувати іконографічні відмінності цієї теми Долинського у різних храмах.

Табл. 2

Порівняльна таблиця відмінностей сюжету

“Зцілення сліпонародженого” в іконографії Л. Долинського

\begin{tabular}{|c|c|c|}
\hline $\begin{array}{c}\text { Собор Св. Юра } \\
\text { у Львові }\end{array}$ & $\begin{array}{c}\text { Церква Зіслання Св. Духа } \\
\text { у Львові }\end{array}$ & $\begin{array}{c}\text { Церква Св. Успіння Бого- } \\
\text { родиці у Почаєві }\end{array}$ \\
\hline $\begin{array}{l}\text { Композиція багатофігурна, } \\
\text { видовжена по горизонталі. } \\
\text { Головна сцена знаходиться } \\
\text { практично у композицій- } \\
\text { ному і оптичному центрі } \\
\text { полотна. Христос і сліпий } \\
\text { оточені групою свідків, гру- } \\
\text { па закомпонаована у формі } \\
\text { розімкнутого півкола; злі- } \\
\text { ва - група спостерігачів- } \\
\text { мешканців, справа - група } \\
\text { апостолів; найближче - } \\
\text { група жінок, рух яких спря- } \\
\text { мовує погляд до головної } \\
\text { сцени але також обмежує і } \\
\text { стримує композицію зліва. } \\
\text { Можливо, серед учасників } \\
\text { дії є фарисей (чоловік в } \\
\text { тюрбані зі скептичним по- } \\
\text { глядом і застережним жес- } \\
\text { том зверненим до Христа). } \\
\text { Середовище дії на тлі місь- } \\
\text { кої архітектури (умовно іс- } \\
\text { торизованої) переходить у } \\
\text { краєвид дальнього плану. } \\
\text { у сцені показано широкий } \\
\text { спектр емоційного відгуку } \\
\text { на чудо - порівн. постаті } \\
\text { жінок і апостолів }\end{array}$ & $\begin{array}{l}\text { Композиція невеличкого } \\
\text { формату, в овалі, зведена } \\
\text { до основної групи: Христос } \\
\text { зцілює незрячого, навко- } \\
\text { лішках перед ним ще один } \\
\text { сліпий. Можливо, представ- } \\
\text { лено інший євангельський } \\
\text { сюжет - зцілення двох слі- } \\
\text { пих (Мт. 9:28) або зцілення } \\
\text { сліпого Вартмея біля Єри- } \\
\text { хону (Мк. 10:46). Ймовір- } \\
\text { но, що ці різні євангельські } \\
\text { оповіді суміщені тут в од- } \\
\text { ній. Позаду Христа (дуже } \\
\text { щільно) зображена група із } \\
\text { чотирьох апостолів (виділя- } \\
\text { ється Йоанн). Від головної } \\
\text { групи віддаляються дві по- } \\
\text { статі з посохами. } \\
\text { Середовище дії - дуже } \\
\text { умовне, намічене ескізно } \\
\text { (позем, кам'яниста дорога), } \\
\text { деякі елементи краєвиду } \\
\text { (фрагмент дерева, кущ, ка- } \\
\text { мені на шляху) розміщені } \\
\text { саме перед групою. } \\
\text { Серед емоцій учнів Христа } \\
\text { присутні цікавість, недові- } \\
\text { ра, сумяятя. } \\
\text { Особливої уваги варті фі- } \\
\text { гури, що віддаляються - як } \\
\text { алегорія нездатних увірува- } \\
\text { ти і прийняти Христа }\end{array}$ & $\begin{array}{l}\text { Великоформатна верти- } \\
\text { кальна композиція. Дія зве- } \\
\text { дена до ближнього плану, } \\
\text { дальній план традиційно } \\
\text { обмежений фрагментами } \\
\text { краєвиду (гора } 3 \text { містом на } \\
\text { ній, дерева). } \\
\text { Головні дійові особи - } \\
\text { Христос і сліпий - оточені } \\
\text { апостолами, які спостеріга- } \\
\text { ють сцену. Образи апосто- } \\
\text { лів більш індивідуалізовані } \\
\text { (завдяки значно більшому } \\
\text { формату полотна). Відчут- } \\
\text { на перевага рисунку над } \\
\text { живописом, сам рисунок } \\
\text { став значно чіткіший, ліній- } \\
\text { ніший. }\end{array}$ \\
\hline
\end{tabular}




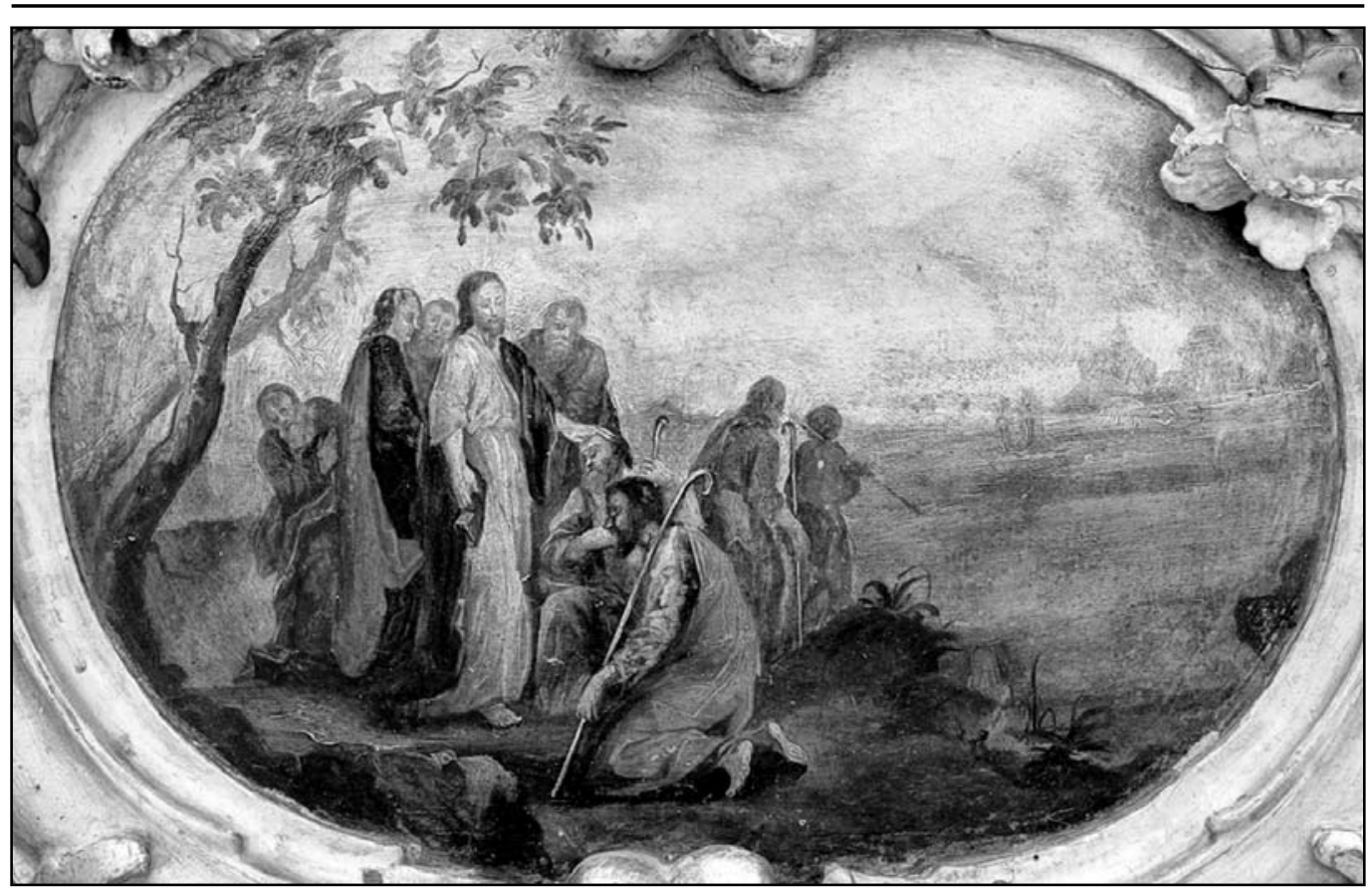

Іл. 3. “Зиілення сліпонародженого”. Худ. Л. Долинський. Церква Зіслання Святого Духа. Львів, 1784 р. Національний музей у Львові ім. А. Шептицького

Порівняння іконографії підтверджує, що Долинський в кожному із сюжетів про зцілення сліпонародженого, виділяючи головну смислову лінію, проробляв тему поновому, залежно від умов і специфіки оздоблення храму (iл. 3). Водночас, розмаїття конструктивних вирішень церковних інтер'єрів XVIII ст. урізноманітнювало не лише форму і обриси окремих ікон, але й впливало на пошуки композиційних рішень, що залежали від конкретної оповіді, але й узгоджувалися з іншими частинами циклу.

В проаналізованих сюжетах “Зцілення сліпонародженого” (навіть за наявності порівняно дрібного формату, що не дозволяв деталізації) важливим для художника було не лише докладно змалювати подію, а передати реакцію на неї глядачів, свідків, учнів Христа. У порівнянні цього окремого сюжету впадає у вічі також поступова зміна живописної манери художника: від легкого і невимушеного авторського малярства рококо iз його розбіленим колоритом, пастозними вкрапленнями білил, прозорими легкими тінями, Долинський в останні роки діяльності перейшов до більшої лінійності, чіткого контуру, великих локальних плям кольору (у Почаєві). У соборі Св. Юра та церкві Зіслання Святого Духа в усіх наративних сюжетах Долинський вільно і декоративно тактує лінії рисунку, що формують людський силует, надаючи фігурам поривчастий, легкий контур; тоді як у Почаївських розписах переважає академічний рисунок.

Наступним сюжетом із циклу Неділь П'ятидесятниці, тричі повтореним Долинським, був сюжет “Христос і самарянка" (Ів. 4:4-26; 1 Кор. 2:14; див. табл. 1), зарахований до празничкового циклу в соборі Св. Юра, іконостасу церкви Зіслання Святого Духа та до композицій у головній наві Успенського собору Почаєва (iл. 4). Символічний зміст цієї події полягає в тому, що у образі “джерела живої води” (Ів. 


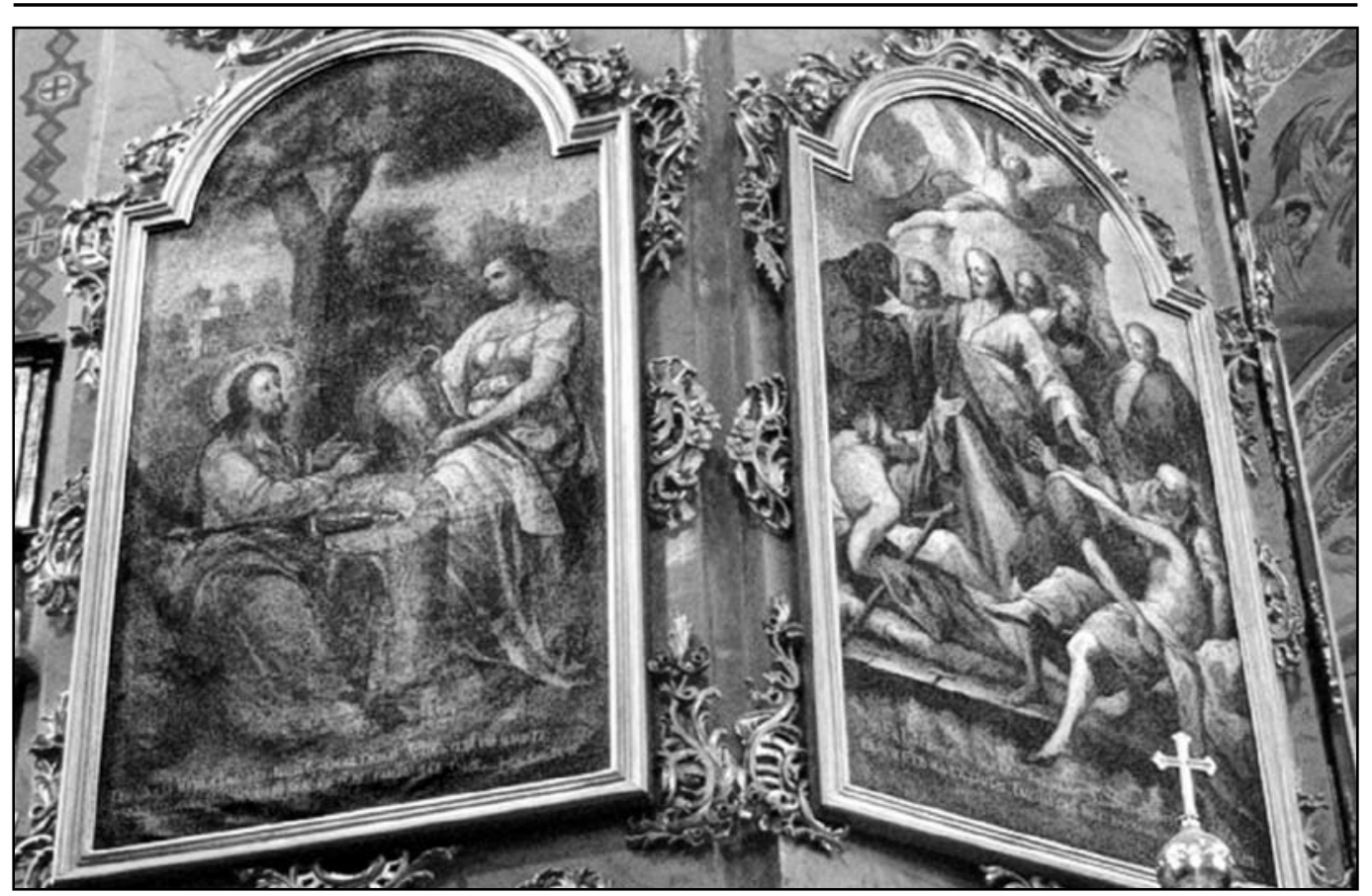

Іл. 4. “Христос і самарянка”. Худ. Л. Долинський. Успенська иеекква. Почаїв, 1807-1810 pp.

4:12-14) виступає сам Христос, віра у якого є джерелом спасіння, а жива вода є даром Святого Духа. Глибшу символіку має також криниця Якова, біля якої відбувається зустріч: ця криниця уособлює “зустріч” старозавітної та євангельської традицій; біля криниці Авраам заключає завіт із Господом і будує там жертовник [17]. У змалюванні сюжету про самарянку в різні епохи художники досить буквально слідували євангельському тексту до дрібних деталей; різні варіанти іконографії були у раніших лицевих Бібліях чи збірниках на зразок Ермінії Діонісія із Фурни (1730р.) [27]. Згадані три композиції на цю тему у Долинського мають майже однакову іконографію, незважаючи на досить значні відмінності у місці розташування та масштабі кожної з них.

Аналізуючи особливості циклу Неділь у доробку Долинського варто детальніше зупинитися на іконостасі для церкви Зіслання Святого Духа, адже саме її посвята була найтісніше пов' язана із тематикою Неділь П'ятидесятниці, відтак тут вказані сюжети доповнювали намісний ряд не випадково. Приміщення семінарської церкви було передано греко-католикам Галичини в 1783 р. і впродовж 1783-1787 рр. в ній велися оздоблювальні роботи. Зокрема, Л. Долинський разом з різьбярем І. Щуровським на замовлення львівського владики П. Білянського виконали для цієї церкви новий іконостас $[28$, с. $41 ; 29$, с. 306]. Цей іконостас заввишки 11 м, ділився на п’ять ярусів і мав окрім чотирьох основних рядів ще один додатковий ряд над намісним [10, с. 199]). У цьому ряді було встановлено шість невеличких композицій у вигадливих рококових картушах: “Христос і Петро на морі”, “Зцілення сліпонародженого”, “Зустріч Марії та Єлизавети”, “Христос і самарянка” , “Святі Тайни” і “Агнець Божий”, з яких дві безпосередньо відносяться до циклу Неділь, а дві останні - опосередковано. 
Проте, зважаючи на загальну структуру іконостасу Л. Долинського, вказані композиції мали досить малий формат і в них художник не міг розгорнути сюжет у повному обсязі. Отож, сюжет про зустріч Христа із самарянкою був змальований у цій церкві доволі лаконічно, знаходячи цікаві паралелі у південнонімецькому і австрійському малярстві другої половини XVIII ст., як от розписи монастиря бенедиктинців у Шафтлярні зі скульптурою Й. Штрауба (Баварія, 1756-1764рр.) та інші композиції невідомих майстрів австрійської школи [30]. Щодо загальної малярської схеми, у Долинського вона не зазнала принципових змін (між 1770-1810-ми рр.) Христос і самарянка ведуть діалог біля криниці, їхня розмова відбувається без свідків.

Доповнюючи міркування про євангельську основу іконографії сцени варто додати, що в давньоюдейській традиції вода цінувалася надзвичайно, а в Новому Завіті “жива вода” (тобто джерельна, колодязна) була одним із символів Святого Духа. Цей образ по-різному змістовно розкривається у семінарійній церкві, де семінаристи грунтовно ознайомлені із тонкощами богослов'я, та у паломницькій церкві Почаєва, до якої прямують тисячі прочан, щоб пересвідчитися у дії цілющої води 3 джерела від чудотворної стопи Богородиці. Тут чудеса здійснюються через воду за посередництвом Святого Духа у більш реальному життєвому контексті.

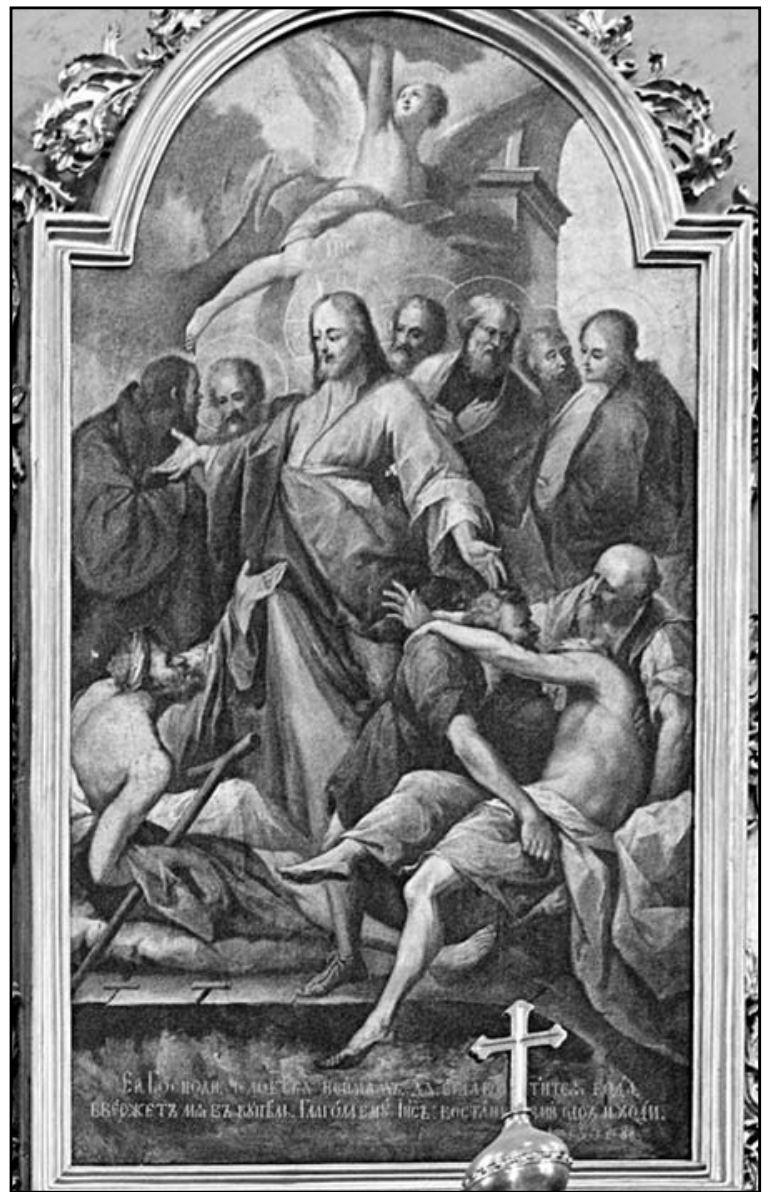

Інша композиція, тематично i символічно пов'язана зі зціленням силою Святого Духа через воду “Зцілення розслабленого” (Ів. 5:2-9) (іл. 5). Подія, що відбулася біля єрусалимської купальні Витезда (або “Бет-Хезда" з арам. із символічною назвою “Дім милосердя”). Здійснене зцілення трактується як акт милосердя [31, с. 34-36].

Іконографічною основою теми $\epsilon$ текст, в якому виділено декілька акцентів:

а) велика кількість хворих біля купальні виступає алегорією духовної немочі світу, нездатності вибратися 3 оков гріха без допомоги Бога (Ів. 5:3);

б) словесний імператив Христа: "Встань, візьми постіль твою і ходи!" - вселяє у хворого віру і силу здійснити наказ. Так, у тому, хто підкоряється Божій волі - діє сам

Іл. 5. "Зиілення розслабленого/Витезда". Худ. Л. Долинський. Успенська иерква. Почаїв, 1807-1810 pp. 
Господь. В сюжеті про зцілення принципово важливими є дві речі: Христос допомагає навіть у безнадійній ситуації (євангеліст уточнює, що хвороба тривала 38 років - Ів. 5:5), а для зцілення, необхідно усвідомити свою духовну хворобу, мати бажання позбутися гріха [17]. У тому, хто слухає заклик Христа - діє сам Бог, через своє слово. Водночас, здійснене чудо $є$ фактом, який лише відсилає до важливішого до значення зустрічі з Богом.

Сцена із розслабленим знаходить паралель із воскресінням Лазаря (цей образ розміщений у Почаєві практично навпроти; з сюжетом про воскреслого Лазаря також пов'язаний сюжет про Тому, який вперше згадується саме у зв'язку із Лазарем (Йо. 11:14-16) [16]. Варто зазначити, що можна прослідкувати внутрішні взаємозв'язки і відсилання між композиціями почаївського циклу: вони є досить

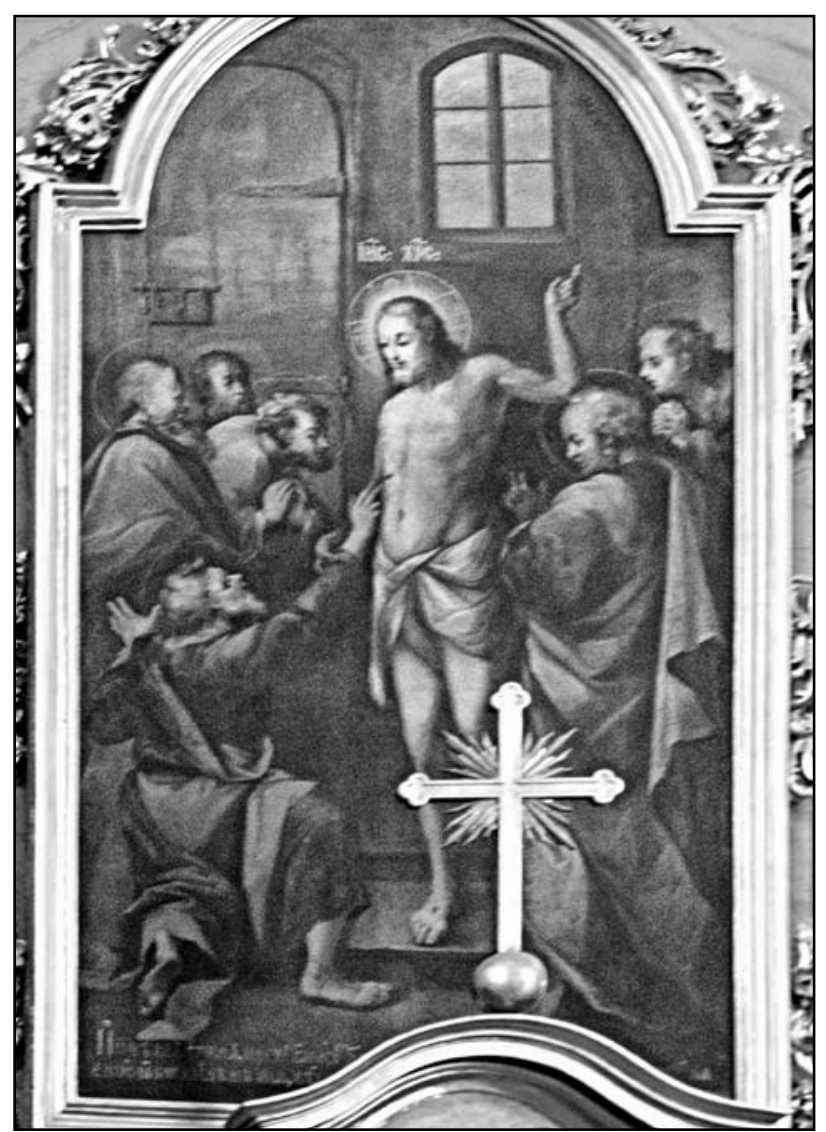

Іл. 6. “Увірування Томи”. Худ. Л. Долинський.

Успенська иерква. Почаїв, 1807-1810 рр. важливими і окремі сцени ніби взаємно підсилюють одна одну. Така система зв' язків між образами призначалася головним чином для духовенства, можливо, прості вірні могли сподіватися на відповідне тлумачення під час проповідей. Проте, не варто відкидати фактор специфічного барокового мислення тогочасних вірних, загалом їх глибокого ознайомлення із біблійними та євангельськими текстами, органічного сприйняття ними алегоричної барокової мови.

Образ “Увірування Томи” представлений лише у почаївському циклі Долинського як великоформатна вертикальна композиція в центральній наві (iл. Ø). Він знаходиться найближче до іконостасу, оскільки надзвичайно важливий і піднесений за змістом [31, c. 21]. На прикладі Томи євангеліст акцентує на розвитку віри, від скептицизму і потреби матеріальних доказів чуда, до відкритого визнання Воскресіння без видимих доказів і людського розуміння події (Йо. 20:27). Після наочного переконання у таїнстві Воскресіння, яке переживає Тома, він дає найурочистіше визнання віри: “Господь мій і Бог мій”, тому важливість цієї формули і їі візуального відображення важко переоцінити.

Долинський розгортає композицію виділяючи два змістовні плани, які є рівноважливими: діалог і взаємодія між Христом і апостолом Томою, відгук на цю зустріч 
апостолів-очевидців. У формальному вирішенні, цей образ цілковито узгоджений із іншими великими композиціями циклу в головній наві. Більше того, сцена "Увірування Томи”, завдяки віднайденому композиційному рішенню, сприймається відкритою до вірних, від символічного простору євангельської події до простору реального храму.

Уважно аналізуючи іконографічні джерела творчості Долинського [32; 33], можна стверджувати, що художник був добре ознайомлений із центральноєвропейським католицьким малярством другої половини XVIII ст. (Баварія, Австрія, Моравія та Угорщина). Серед митців, що оздоблювали пізньобарокові храми вказаного регіону були попередники і вчителі Долинського, випускники і викладачі Віденської мистецької академії (Ф. Маульберч, Ф. Фішер,. К. Замбах та інші) [11; 33]. В подібних монументальних проектах для переважно паломницьких католицьких церков наратив євангельських чудес і притч, доповнений старозавітніми алегоріями, займав досить значну частину [34]. Подібно, як сюжет про Христа і самарянку, тема "Увірування Томи” була надзвичайно популярною в малярстві Центральної Свропи. Серед кращих зразків можна згадати розписи монастирської церкви в Етталі (1757-1765 рр., Баварія) чи образ у церкві в Бад Шуссенрюд (1746 р., Верхньошвабський бароковий шлях) [35]. Своєрідність історії Томи у світогляді людини епохи бароко можна пояснити словами св. Григорія: “Тома бачив одне, але повірив в інше; він бачив чоловіка зі шрамами і через це повірив у божество Воскреслого” [31, с. 21].

Підсумовуючи огляд живописних вирішень Неділь П'ятидесятниці, виконаних Л. Долинським у головних унійних храмах Львова та Почаєва, можна припустити, що в розробці ідейно-богословської програми розписів Л. Долинський не міг бути одноосібним автором. За тематичними паралелями, алегоричним наповненням і багаторівневим символізмом сюжетів проглядається послідовний вплив представників духовенства. Зважаючи на зміну принципів опорядження унійних храмів у першій половині XVIII ст. та суттєві трансформації в композиції іконостасу у другій половині XVIII ст., що мали значний вплив на обмеження кількості празничкових тем, спостерігався відбір нових сюжетів, головно із циклу Неділь. Втім, тематика циклу не впроваджувалася цілісно, а в кожному конкретному випадку обиралися певні мотиви, які найповніше відображали посвяту храму та загальну іконографічно- малярську програму. Незважаючи на вплив замовників (кліру) у формуванні цих програм, індивідуальний рівень інтерпретації у Долинського проявлявся не у відборі сюжетів, а саме у способах їх живописного вирішення, у авторському переосмисленні окремих сцен та яскравій манері виконання. Тематика циклу Неділь П'ятидесятниці у корпусі творів Л. Долинського не лише займала важливе місце, але й демонструвала відгук художника на актуальні тенденції більш широкого релігійно-мистецького контексту.

1. Голубець М. Долинський. Львів, 1924. 26 с.

2. Щурат В. Лука Долинський // Світ. 1917. Ч. 3. С. 40-42.

3. Александрович В., Ричков П. Собор Святого Юра у Львові. Київ: Техніка, 2008. С. 185-192.

4. Ричков П. А., Луц В. Д. Почаївська Свято-Успенська Лавра. Київ, 2000. 134 с.

5. Федорів Ю., о. д-р. Замойський Синод 1720 р. // Богословія. Рим 1971. Т. XXXV(35). C. 5-6, 58-61. 
6. Кобрин М. Замойський синод і формування традиційної ідентичності УГКЦ // Вісник Львівського національного університету ім. І. Франка. Серія історична. Львів, 2012. Вип. 15. C. $235-240$.

7. Вуйцик В. Архикатедра Святого Юра у Львові: Архітектурний ансамбль // Вісник ін-ту “Укрзахідпроектреставрація". Львів, 1994. Ч. 14. С. 17-22.

8. Вуйцик В. Монастир Св.Онуфрія у Львові // Вісник' 2004 (Науковий вісник інт-ту “Укрзахідпроектреставрація"). Львів, 2004. С. 48-60.

9. Овсійчук В. Класицизм і романтизм в українському мистецтві. Київ: Дніпро, 2001. C. 202-205.

10. Сидор О. Іконостасні ансамблі Луки Долинського (традиція та пошук нових форм і засобів мистецького вислову) // Апологет. Львів, 2010. № 4. С. 196-202.

11. Левицька М. Віденський досвід Луки Долинського (1775-1777 роки) // Записки НТШ. Львів, 2011. T. CCLXI. С. 223-232. (Праці комісії образ. та ужит. мистецтва).

12. Левицька М. Зображення апостолів і пророків в іконостасних циклах Луки Долинського (кін. XVIII - початок XIX ст.): пошуки образної виразності // Християнська сакральна традиція: віра, духовність, мистецтво: зб. матеріалів IX Міжнар. конф. Львів: ЛПБА УПЦ КП, 2016. С. 255-271.

13. Святе письмо Старого та Нового Завіту / пер. на укр. United Bible Societies. [B. m.], 1991. Старозавітні свідчення про Зіслання СВ. Духа: Чс 11:16-17; Йоїл 2:23-32; Сз 36: 24-28; Бут.3:15; Йов. 19:25; Пс 8:6; Іс.53: 1-12.

14. Іванчо І. Ікона і літургія / пер. 3 угор. о. Л. Пушкаш. Львів: Свічадо, 2009. С. 393-417, 485-498.

15. Архиєпископ Ігор (Ісіченко). Майте любов поміж собою: зб. проповідей. Львів-Харків: Святогорець, 2010. 456 с. (Проповідь на 6-ту неділю після П'ятидесятниці - Зцілення розслабленого). URL: https://kyrios.org.ua/propovidi/propovidi-na-nedili-i-svjata/29407-propovidna-6-tu-nediliu-pislia-piatydesiatnytsi-ztsilennia-rozslablenoho-ihor-isichenko-2013.html (дата перегляду - 14. 09. 2015).

16. Протоиерей Григорий Дебольський. Недели и другие дни Цветной Триоди, или Пятидесятницы. URL: http://www.omolenko.com/bogosluzhenia/p708-p713.htm.

19. Tradigo A. Icons and Saints of the Eastern Orthodox Church. Milan: Mondodori Electa, 2004. P. 154.

20. Зілінко Р. Ряд неділь П'ятидесятниці з жовківського іконостасу Івана Рутковича (Матеріали до каталогу творів Івана Рутковича в НМЛ ім. А. Шептицького) // Літопис НМЛ. Львів, 2006. № 4 (9). С. 143-150.

21. Ярема В. Традиції і нововведення у побудові іконостасів XVII-XVIII ст. // Православний вісник. Київ, 1972. № 5-6. С. 18-22.

22. Giemza J. Ikonostas z cerkwi p.w. Swietego Mikolaja w Lubaczowie. Ukrainska sztuka cerkiewna 17 wieku wobec tradycyjnych wartosci ideowo-estetycznych // Polska-Ukraina: spotkanie kultur. [Б. м.], 1997. S. 44.

23. Janocha M. Ukraińskie i białoruskie ikony świąteczne w dawnej Rzeczpospolitej. Warszawa, 2001. S. 126-128.

24. Szanter Z. Rola wzorów zachodnich w ukształtowaniu ikonostasu w XVII w. na południowo wschodnim obszarze Rzeczpospolitej // Teka Konserwatorska. Polska Południowo - Wschodnia, 1985. S. 93-135.

25. Пелех М. Іконографія пределл: рідкісна іконописна символіка сюжетів з церкви Успення пресвятої Богородиці у Мор'янцях на Яворівщині // Апологет (Християнська сакральна традиція: віра, духовність, мистецтво). Львів, 2010. С. 162-168. 


\section{Науковий щорічник “Історія релігій в Україні”. 2019. Вип. 29.}

26. Драган М. Українська декоративна різьба XVI-XVIII ст. Київ:Наукова думка. 1970. С. 156.

27. Эрминия или наставление в живописном искусстве, составленное иеромонахом и живописцем Дионисием Фурноаграфиотом. URL: http://nesusvet.narod.ru/ico/books/erminiya. $\mathrm{htm}$ (дата перегляду - 12.04.2015).

28. Островський В. Нове про художника Луку Долинського // Архіви України. 1966. № 2. С. 41.

29. Вуйцик В. Скульптор Іван Щуровський // Записки НТШ. Львів, 1998. Т. 236. С. 305-313. (Праці мистецтвознавчої комісіі).

30. Abtei Schaftlarn. Klosterkirche. URL: http://www.abtei-schaeftlarn.de/kunst-kultur/ klosterkirche/ (дата перегляду - 12.09.2016).

31. Коментарі на недільні Євангелія. Львів: Свічадо, 2015. С. 21, 33-36, 44-45.

32. Lanzi G. Das Buch der Heiligen: Kunst, Symbole und Geschichte. Belser, 2003. 240 s.

33. Hindelang E. (ed.), Franz Anton Maulbertsch und der Wiener Akademiestil. Verlag: Sigmaringen-Thorbecke, 1994. $348 \mathrm{~s}$.

34. Святе Письмо в європейській культурі: біблійний словник. Київ: Дух і літера, 2004. 320 с.

35. Beck O., Ingeborg Buck I. Oberschwäbische Barockstraße. Ein Reisebegleiter für Kunstfreunde. Schnell \& Steiner, Regensburg, 1997. 112 s.

\section{SUMMARY}

\section{Mariana Levytska \\ Plots of "Sundays of Pentecost" in iconostasis cycle painted by Luka Dolynskyi: symbolics and iconography}

The main object of the research is a selected group of the religious paintings belonging to the iconostasis created by Luka Dolynskyi for several churches in Lviv and Pochayiv from 1770s to $1820 \mathrm{~s}$. This investigation is the part of the great case study of the art heritage of Luka Dolynskyi in the comparative context of the Central European late Baroque ecclesiastical art.

Although the analyzed paintings were linked to the Sundays of Pentecost cycle, depicting the special period of the liturgical year they were not commonly used in Ukrainian iconostasis until the end of 17th century. These motives complemented the Twelve Great Feasts iconic cycle which was the essential part of the Ukrainian iconostasis from the 16th century.

While working on the iconostasis of the mentioned churches, Dolynskyi modified the traditional range of topics and introduced some new compositions into them. Among the themes that were constantly encountered in the artist's works were the themes of the Sundays of Pentecost. Such Gospel events as "Healing a blind", "Healing a paralytic", "Christ and Samaritan woman" or "The Incredulity of Saint Thomas" were distinctly connected with substantial issues of the faith and piety actualized by Uniate higher clergy after the Zamoyskyi Synod of 1720.

Symbolics and iconography of the selected paintings and their interdependence with Uniate clergy intentions to influence church art of the 18th century are researched. It should be mentioned that changes in the general principles of church decoration and transformation of the traditional composition of iconostasis had significantly limited the motives. The iconographical peculiarities of the Pentecost weeks cycle in general aspects, as well as the special Uniate theological background of the Dolynskyi artworks are analyzed.

The following study of these paintings in a specific local context has revealed the symbolic meaning of the Gospel topics depicted in ecclesiastical art. The relevance of the article is supplemented by a comparative context for the identification of mutual influence in Western and Eastern iconography of the scenes of "Sundays of Pentecost".

Keywords: cycle of "Sundays of Pentecost", theological basis, iconographic program, symbolics of motives 